\title{
ІННОВАЦЙНЕ ПІДПРИЕМНИЦТВО ТА СТАРТАПИ ДЛЯ СТАБІЛІЗАЦІЇ ЕКОНОМІКИ: СВІТОВИЙ ДОСВІД ТА ЗАСТОСУВАННЯ В УКРАЇНІ
}

\author{
Троц Ірина Вікторівна, \\ кандидат економічних наук, \\ дочент кафедри теоретичної та прикладної економіки, \\ ВНЗ «Університет економіки та права «КРОК», \\ ORCID: https://orcid.org/0000-0001-9608-0591,
}

\begin{abstract}
Дзюбко Віктор Васильович старший викладач кафедри теоретичної та прикладної економіки, ВНЗ «Університет економіки та права «КРОК» ORCID: https://orcid.org/0000-0003-0759-457X
\end{abstract}

\begin{abstract}
Анотація. У розділі досліджується зв'язок між розвитком інноваційного підприємництва, з одного боку, та стабілізацією в умовах економічної невизначеності - 3 іншого. Розглянуто успішні форми інноваційного підприємництва - стартапів у інших країнах та в Україні. Зроблено узагальнення стосовно факторів сприяння та обмеження інноваційного підприємництва. Досліджено національні моделі інноваційного розвитку й інструменти сприяння інноваційному підприємництву у формі стартапів. Визначено особливості інноваційної діяльності в Україні та окреслено умови та можливі перспективи іiі подальшого розвитку, 3 огляду на високий рівень економічної невизначеності.
\end{abstract}

Ключові слова: інноваційна діяльність, стартап, інноваційне підприємництво, національна інноваційна модель розвитку, рейтинги стартапів, фонд розвитку стартапів.

Дослідження інноваційного підприємництва $є$ актуальним для української економіки та суспільства, які потерпають від недовикористання інтелектуального та природного потенціалу країни. Ми припускаємо, що традиційні форми організації підприємницької діяльності, здебільшого, вичерпали свої можливості. Тому перспективними, з огляду на необхідність стабілізації національної економіки, стають принципово нові, креативні форми провадження підприємництва. Саме таку новизну форми та змісту демонструють стартапи. Попри існування сотень досліджень, здійснених фахівцями різних країн у царині інноваційної діяльності й стартапів, існують лакуни в аналізі можливостей і обмежень такої діяльності саме в Україні. Потребує відповіді питання про потенціал інноваційного підприємництва для стабілізації та досягнення вищого рівня визначеності української економіки. 
Метою цього дослідження є актуалізація проблеми українського інноваційного підприємництва та його організаційної форми - стартапів підприємств, які започатковують принципово нове виробництво. Ідеться, зокрема, про ідентифікацію й оцінювання можливостей та перешкод на шляху реалізації такої діяльності в Україні. Ідентифікація й оцінювання здійснюються 3 метою з'ясування впливу інноваційної сфери на стабілізацію підприємництва та визначеність економіки.

Ми спиратимемося на низку ключових понять, без чіткого окреслення змісту яких не може бути досягнута мета дослідження. Це такі поняття, як інноваційна діяльність, інноваційне підприємництво, моделі інноваційного розвитку країни, стартапи. Не акцентуючи увагу на деталях, визначатимемо основне у змісті згаданих понять.

Інноваційна - це діяльність, що має такі визначальні ознаки:

- спрямована на створення нового або суттєво вдосконаленого продукту, технологічного процесу, способу надання послуг;

- безпосередньо пов'язана з удосконаленням знань, з науковими дослідженнями та розробками інноваційних ідей, що втілюються у принципово нові товари, послуги, технології, які користуються попитом споживачів.

Інноваційне підприємництво - особливий вид економічної діяльності, орієнтований на інновації, що має такі ознаки:

- передбачає перманентний пошук нових можливостей та орієнтоване на здійснення нових проєктів;

- стикається на початкових етапах реалізації з відносно більшими ризиками, тому передбачає організаційні та економічні запобіжники й вищу відповідальність ініціаторів;

- вмотивоване перспективою отримання інноваційних (суттєво вищих від середніх) прибутків або інших вигод;

- формує значні конкурентні переваги на ринку.

Успіх інноваційної діяльності визначається економічною політикою урядів країн, станом національних ринків та рівнем макроекономічної стабільності. 3 огляду на це, є підстави для виокремлення поняття (й відповідного явища) «національні моделі інноваційного розвитку». Інформація про найбільш відомі та такі, що мають чіткі ознаки, моделі ілюстровано на рис. 1 .

На рис. 1 ілюстровано три моделі інноваційного розвитку, адаптовані до конкретних умов окремих країн.

Вагомою перевагою стрімкого розвитку інноваційної діяльності у розвинених країнах $є$ багатоканальність та варіативність джерел фінансування й стимулювання. Зокрема, фінансування науково-дослідних і дослідно-конструкторських робіт (НДДКР) та інноваційної діяльності у США, Японії, країнах Західної Свропи характеризується поєднанням різних джерел. $€$ підстави для виокремлення таких каналів фінансування інноваційної діяльності з відповідними джерелами (рис. 2). 


\begin{tabular}{|c|c|}
\hline $\begin{array}{c}\text { Орієнтовані на лідерство } \\
\text { в науці й інноваційному } \\
\text { розвитку }\end{array}$ & $\begin{array}{l}\text { - спрямовуються значні (у \% до ВВП) фінансові } \\
\text { ресурси на фундаментальні та прикладні } \\
\text { дослідження, реалізуються цільові й комплексні } \\
\text { форсайт-проєкти з моделювання майбутнього; } \\
\text { - } \boldsymbol{C} \boldsymbol{A}, \text { Велика Британія, Франція }\end{array}$ \\
\hline
\end{tabular}

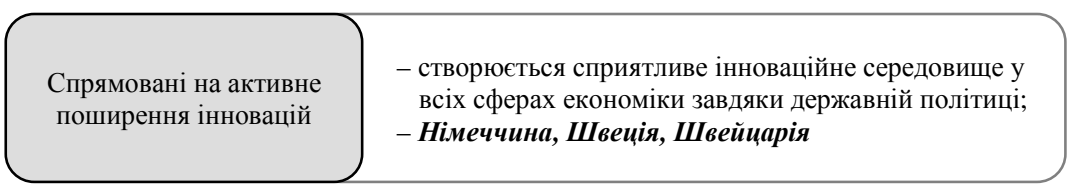

Сприятливі щодо реалізації досягнень світового науковотехнічного прогресу
- активно координуються дії влади та бізнесу в напрямку реалізації всіх можливих видів інновацій;

- КНР, Японія, Південна Корея

Рис. 1. Моделі інноваційного розвитку економічно розвинених країн

Джерело: сформовано авторами на основі [1].

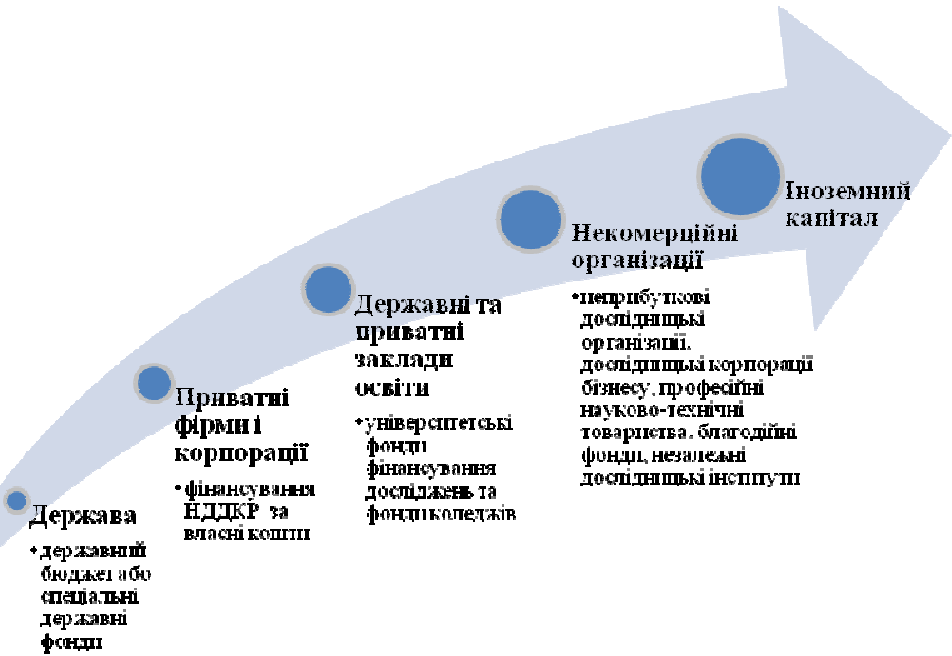

Рис. 2. Основні джерела фінансування інноваційної діяльності у розвинених країнах

Джерело: сформовано авторами самостійно.

На рис. 2 ілюстровано п'ять каналів фінансування науково-дослідної діяльності, які охоплюють внутрішні державні, створені колективно та приватно, а також зовнішні джерела.

3 досвіду США, Японії, Німеччини, Великої Британії, Франції та Канади випливає необхідність і доцільність стимулювання інноваційного 
підприємництва за рахунок бюджетних коштів. Вирішальним інструментом такого фінансування стає інноваційна політика держави. У країнах 3 розвиненою ринковою економікою уряди фінансують від 20 до 50\% національних наукових інноваційних витрат. Частка витрат на дослідницькі роботи та інноваційні розробки в загальній сумі державних витрат $\epsilon$ невеликою. Але впродовж 20 років вона залишається стабільною і становить у США 6-7\%, у Німеччині, Франції, Великий Британії та Італії - 4-5\%, в Японії - 3-5\% [1].

Важливим джерелом фінансування ризикового інноваційного капіталу в економічно розвинених країнах можуть ставати банки, пенсійні фонди, страхові компанії. Але в різних країнах частки та впливовість згаданих джерел є різною.

Світовий досвід свідчить про ефективність венчурного фінансування, яке передбачає прямі інвестиції на ранній стадії реалізації проєктів у високотехнологічних сферах. Як відомо, таке фінансування стає рятівним для підприємств з обмеженим доступом до банківських кредитів. Венчурне фінансування малих і середніх підприємств сприяло технологічному розвитку в сферах біотехнології, інформаційних технологій, напівпровідникової електроніки, обчислювальної техніки. Найбільшого поширення венчурне фінансування досягло в США, Німеччині, Великій Британії, Японії, Нідерландах. Якщо у США левова частка венчурного фінансування припадає на IT-підприємства, то в Західній Європі венчурні інвестиції досить рівномірно розподіляються між різними галузями та сферами. Аналіз міжнародного досвіду формування інноваційних економік і організації інноваційного підприємництва дає підстави для виокремлення таких важливих моментів інноваційної діяльності, як: фактори сприяння інноваційній діяльності (фактори стимулюючого впливу); фактори, що уповільнювали інноваційну діяльність (фактори стримуючого впливу); організаційні форми (інститути підтримки) інноваційної діяльності. Виокремлені моменти інноваційної діяльності подано в аналітичній табл. 1.

В аналітичній табл. 1 подано інформацію про сприятливі та несприятливі для інноваційної діяльності фактори впливу. Вони виявилися в діяльності не лише інноваційних лідерів світу, а й країн швидкого просування в інноваційній сфері. Й тих, й інших можна ідентифікувати як інноваційних інсайдерів. Для країн інноваційних аутсайдерів особливо корисним є досвід створення організаційних структур (інститутів стимулювання) інновацій. Адже саме інститути забезпечують дію факторів стимулювання.

Апробованою та результативною в багатьох країнах формою інноваційних підприємств $є$ «стартапи». Існують різні тлумачення змісту цього поняття. Для науковців та практиків країн, які запозичують досвід стартапів, важливо враховувати різні аспекти цього змісту. Тому ми акцентуємо увагу саме на особливостях тлумачення змісту. 


\section{Фактори та інститути інноваційної діяльності}

\begin{tabular}{|c|c|c|}
\hline $\begin{array}{c}\text { Фактори } \\
\text { стимулюючого впливу }\end{array}$ & $\begin{array}{c}\text { Фактори } \\
\text { дестимулюючого впливу }\end{array}$ & $\begin{array}{c}\text { Організаційні форми } \\
\text { (інститути) підтримки } \\
\text { інноваційної діяльності }\end{array}$ \\
\hline $\begin{array}{l}\text { - послідовна і довгострокова } \\
\text { інноваційна політика } \\
\text { держави з чітко } \\
\text { сформульованими цілями та } \\
\text { інструментами; } \\
\text { - раціональне використання } \\
\text { інноваційного потенціалу } \\
\text { для формування нового типу } \\
\text { економіки - інноваційної; } \\
\text { - системна взаємодія } \\
\text { приватного, науково- } \\
\text { дослідного та освітнього } \\
\text { секторів; } \\
\text { - цільова підтримка важливих } \\
\text { для формування } \\
\text { інноваційного потенціалу } \\
\text { напрямків діяльності, які не } \\
\text { можуть розвиватися на } \\
\text { основі власних ресурсів; } \\
\text { - реалізація програм } \\
\text { комерціалізації інновацій; } \\
\text { - доцільне з огляду } \\
\text { національних інтересів } \\
\text { залучення іноземних } \\
\text { інвестицій транснаціональних } \\
\text { корпорацій; } \\
\text { - законодавство з захисту прав } \\
\text { інтелектуальної власності та } \\
\text { його послідовна реалізація; } \\
\text { - систематичне вивчення та } \\
\text { адаптація кращого } \\
\text { міжнародного досвіду. }\end{array}$ & $\begin{array}{l}\text { - відносно низька частка } \\
\text { приватного бізнесу у } \\
\text { фінансуванні НДДКР } \\
\text { (Франція, Швеція, } \\
\text { Нідерланди, Індія); } \\
\text { - відстороненість малого } \\
\text { бізнесу від інноваційної } \\
\text { діяльності (Франція, } \\
\text { Швеція, Нідерланди, } \\
\text { Японія); } \\
\text { - «витік мізків» - міграція } \\
\text { кваліфікованих } \\
\text { працівників (Франція, } \\
\text { Німеччина); } \\
\text { - територіальні диспропорції } \\
\text { в інноваційному розвитку } \\
\text { (Німеччина, Індія, Китай, } \\
\text { Франція, Норвегія); } \\
\text { - швидке старіння населення } \\
\text { (країни Європейського } \\
\text { Союзу); } \\
\text { - нерозвинені ринки } \\
\text { венчурного капіталу } \\
\text { (Данія, Німеччина); } \\
\text { - організаційно-правові } \\
\text { перепони на шляху } \\
\text { комерціалізації інновацій } \\
\text { (Індія, Німеччина, Бразилія); } \\
\text { - «забюрократизованість» } \\
\text { процедур, пов’язаних з } \\
\text { підприємницькою } \\
\text { діяльністю (Індія, } \\
\text { Бразилія, країни Азії). }\end{array}$ & $\begin{array}{l}\text { - спеціальні організації } \\
\text { та органи, відповідальні } \\
\text { за визначення і } \\
\text { реалізацію інноваційної } \\
\text { політики (майже всі } \\
\text { країни); } \\
\text { - активна взаємодія з } \\
\text { іншими країнами в } \\
\text { обміні технологіями } \\
\text { (майже всі країни); } \\
\text { - створення інноваційних } \\
\text { кластерів (Франція, } \\
\text { Німеччина); } \\
\text { - здійснення основних } \\
\text { інновацій у співпраці з } \\
\text { транснаціональними } \\
\text { корпораціями (Швеція, } \\
\text { Франція, Нідерланди, } \\
\text { Індія, Японія); } \\
\text { - організаційне } \\
\text { забезпечення } \\
\text { безкоштовної освіти, } \\
\text { орієнтованої на } \\
\text { виявлення та просування } \\
\text { талановитої молоді } \\
\text { (Німеччина, Норвегія); } \\
\text { - використання } \\
\text { «інноваційних } \\
\text { ваучерів» (Нідерланди, } \\
\text { Велика Британія, } \\
\text { Німеччина). }\end{array}$ \\
\hline
\end{tabular}

Джерело: складено авторами на основі [1].

Як відомо, термін «стартап» пов'язаний 3 назвою малого підприємства «Start Up», заснованого у США двома студентами Стенфордського університету. Йдеться про У. Хьюлетта та Д. Паккарда, які пізніше стали творцями всесвітньо відомої компанії у сфері інформаційних технологій - Hewlett-Packard. Відтак, при вживанні поняття «стартап» виникає асоціація з підприємством, що забезпечує прорив у певній сфері, реалізує принципово нову ідею та швидко зростає.

Відомий американський підприємець Стів Бланк, який створив вісім успішних стартапів, визначав стартап як організацію, що «сформована 
для пошуку повторюваної і масштабованої бізнес-моделі» [2]. У цьому визначенні акцентовано увагу на започаткуванні того, що повторюється іншими та набуває поширення.

Визнаний фахівець у сфері венчурного капіталу Пол Грем, який став засновником Y Combinator та Yahoo! Store i написав книгу «Хакери та Художники», зазначав таке: це «компанія, спроєктована з метою швидкого зростання» [3]. У цьому визначенні акцентована обставина динамічності розвитку бізнесу.

Американський ініціатор руху «Ощадливий стартап», спеціаліст у сфері управління бізнесом високих технологій Ерік Ріс зазначає, що «стартап - це людський інститут, спроектований для створення нового продукту або сервісу в умовах критичної невизначеності» [4]. Наведене визначення цікаве тим, що в ньому акцентовано увагу на новизні створюваного продукту та на необхідності діяти за умов невизначеності.

У роботі «Священна книга стартапера. Як збудувати успішну компанію» Стіва Бланка та Боба Дорфі [5] подано декілька визначень стартапів:

- стартап - це процес виходу на ринок новоствореної компанії за короткі терміни і, як правило, при мінімальних вкладеннях;

- стартап - це не зменшена версія великої компанії, а організація, що займається пошуком прибуткової бізнес-моделі, яку можна масштабувати;

- стартап - це форма бізнесу, яка передбачає випробування не тільки фінансових можливостей іiі ініціаторів, а й їхньої витримки, спритності та сміливості;

- стартап - це проєкт реалізації набору неперевірених гіпотез 3 надзвичайно високими ризиками.

Найбільш доречним нам видається визначення, за яким стартап - це нещодавно створена компанія, яка формує свій бізнес на основі інновацій (інноваційних технологій), має у розпорядженні обмежені ресурси та орієнтована на швидкий розвиток та завоювання нового сегменту ринку.

На перший погляд, кожна новостворена компанія може називатися стартапом. Але таке тлумачення є хибним. Те, що принципово відрізняє стартап від звичайного новоствореного підприємства, віддзеркалено на рис. 3.

Суть поданої на рис. 3 ідеї у тому, що стартап відрізнається від звичайного новоствореного підприємства принаймні за чотирма ознаками, а саме: за інноваційністю проєкту, за браком інвестицій через високу ризиковість проєкту, за орієнтованістю на швидке зростання та за низькою ймовірністю успішності. 


\section{Інноваційність ідеї проєкту}

- зазвичай стартапи пов'язані з новими продуктами та послугами, що створюють новий сегмент ринку

Обмеженість початкових інвестицій, насамперед через невизначеність результатів та високі ризики інвестування

- здебільшого, початкові інвестиції стартапів - це власні кошти засновників проєкту та їх оточення, що формують так званий стартовий капітал

Орієнтованість на швидкий розвиток та швидке отримання переваг

- стартапи створюються, в середньому, впродовж 3-4 місяців, винятком можуть стати лише високотехнологічні стартапи, на «запуск» яких може знадобитися до року

Низька ймовірність на успіх проєктів

- за статистикою, 70\% стартапів зникають у перший рік, а з тих, що продовжують існувати, ще $40 \%$ не досягає дворічного терміну

\section{Рис. 3. Ключові відмінності стартапів від звичайних компаній} Джерело: створено авторами самостійно.

Окрім чотирьох зазначених особливостей змісту, стартап, як форма бізнесу, має певні особливості так званого «життєвого циклу». Повний «життєвий цикл стартапу», на наш погляд, охоплює такі 5 етапів (рис. 4). Переважна більшість стартапів припиняє існування на перших трьох етапах.

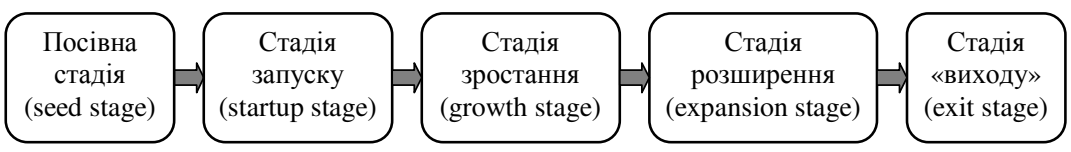

\section{Рис. 4. «Життєвий цикл» стартапів}

Джерело: розроблено авторами на основі [6].

Ілюстровані на рис. 4 етапи «життєвого циклу» стартапів мають такі особливості:

- «nосівна стадія» передбачає формування стартового капіталу після підготовки паперового варіанту бізнес-проєкту;

- «стадіï запуску» $є$ початком практичної діяльності та позиціювання на ринку;

- «стадія зростання» характеризується досягненням нормальних (очікуваних) значень основних економічних показників: випуску, продажів, прибутку тощо; 
- «стадія розширення» означає зростання масштабів справи через додаткові інвестиції в персонал, основний капітал, офісні площі тощо, а також отримання високих «інноваційних» прибутків, які компенсують попередні ризики та корелюють 3 унікальністю (інноваційністю) продукту;

- «стадія виходу» пов'язана з завершенням «життєвого циклу» стартапу, що може поєднуватися з набуттям ознак «звичайної» компанії, 3 масовим відтворенням раніше інноваційної ідеї іншими підприємцями, а також з виходом з компанії засновників та продажем пакету акцій, яким вони володіли.

У науковій та публіцистичній літературі послуговуються й іншими класифікаціями етапів «життєвого циклу» стартапів. Попри відмінності підходів, однак, можна констатувати таке:

- стартапи перебирають на себе ризики невизначеності на початкових етапах свого існування;

- ті зі стартапів, які не припиняють свого існування на початкових етапах, на пізніших етапах додають визначеності для інших форм бізнесу та всієї національної економіки.

За результатами аналізу світового досвіду розвитку стартапів дослідники роблять узагальнення, що спираються на незаперечні факти.

По-перше, державна підтримка інноваційної діяльності відіграє визначальну роль у зростанні кількості стартапів та в їх успішному розвиткові. Керівництво ЄС загалом та уряди Німеччини, Франції, Фінляндії, Австрії, Ірландії, Швеції, Норвегії, зокрема, втілюють програми підтримки стартапів. Цим інноваційним підприємствам надаються кредитні та податкові пільги, гранти для студентів, перспективних випускників навчальних закладів, для окремих підприємців, створюється сприятливе середовище для венчурних інвесторів. Нові члени СС Польща, Чехія, Литва, Угорщина - також стали активними учасниками процесу підтримки інноваційного підприємництва [7].

По-друге, політика урядів країн, які є інсайдерами - лідерами та активними діячами інноваційної сфери - має декілька спільних рис. Це чітке розмежування сфер повноважень державних, регіональних i місцевих органів влади, що дозволяє уникнути дублювання функцій, імплементація у світові інноваційні процеси на засадах міжнародної кооперації, включно з трансфером технологій, реформування законодавства під потреби інноваційних підприємств [8].

По-третє, успішними стають стартапи, які створюються у сферах задоволення найбільш актуальних потреб або ті, що такі потреби формують та підтримують. Про це, зокрема, свідчить інформація 3 сайту «StartupRanking» про рейтинг стартапів світу. Ранжування стартапів У рейтингу здійснюється на основі так званої оцінки SR, яка відображає 
важливість стартапу в Інтернеті (оцінка SR Web) і його соціальний вплив (SR Social).

У табл. 2 подано 10 найвідоміших стартапів, за рейтингом «StartupRanking» у 2020 p.

Таблиця 2

Tоп 10 стартапів у світовому рейтингу за «StartupRanking»

\begin{tabular}{|c|c|c|c|c|c|}
\hline Ранг & Стартап & $\begin{array}{l}\text { Засно- } \\
\text { ваний }\end{array}$ & $\begin{array}{l}\text { Оцінка } \\
\text { SR }\end{array}$ & Опис & $\begin{array}{c}\text { Ранг } \\
\text { країни }\end{array}$ \\
\hline 1 & $500 \mathrm{px}$ & 2009 & 89,794 & $\begin{array}{l}\text { Прем’єр-фотографічне співтовариство } \\
\text { для нагромадження кращих зображень } \\
\text { в Інтернеті }\end{array}$ & Канада \\
\hline 2 & Canva & 2012 & 89,645 & $\begin{array}{l}\text { Програмне забезпечення для } \\
\text { графічного дизайну }\end{array}$ & Австралія \\
\hline 3 & Coursera & 2012 & 88,178 & $\begin{array}{l}\text { Безкоштовні онлайн-курси від кращих } \\
\text { університетів }\end{array}$ & США \\
\hline 4 & Duolingo & 2011 & 88,171 & $\begin{array}{l}\text { Безкоштовна мовна освіта для всього } \\
\text { світу }\end{array}$ & Гватемала \\
\hline 5 & Freelancer & 2009 & 88,085 & $\begin{array}{l}\text { Найбільший у світі ринок фрілансингу } \\
\text { та краудсорсингу }\end{array}$ & Австралія \\
\hline 6 & Teespring & 2011 & 87,665 & $\begin{array}{l}\text { Платформа, яка дозволяє кожному } \\
\text { створювати та продавати високоякісні } \\
\text { продукти }\end{array}$ & США \\
\hline 7 & Giphy & 2013 & 87,636 & Анімований пошук у GIF & США \\
\hline 8 & Telegram & 2013 & 87,607 & Додаток з обміну повідомленнями & Росія \\
\hline 9 & IFTTT & 2010 & 87,382 & $\begin{array}{l}\text { Отримання великих масивів } \\
\text { інформації при поєднання існуючих } \\
\text { онлайн-сервісів - Facebook, Twitter } \\
\text { тощо }\end{array}$ & США \\
\hline 10 & TransferWise & 2010 & 87,362 & $\begin{array}{l}\text { Перекази грошей в Інтернеті, } \\
\text { надсилання грошей за кордон }\end{array}$ & \begin{tabular}{|l} 
Велика \\
Британія
\end{tabular} \\
\hline
\end{tabular}

Докерело: згруповано авторами [9].

За інформацією, поданою в табл. 2, найбільш успішні стартапи у 2020 році діяли у таких сферах, як фото- та графічне редагування, онлайн-курси та платформи для освіти, дистанційної роботи через віддалений доступ, продажу товарів через інтернет-платформи, GIFанімація, створення баз даних про потреби споживачів, грошові онлайн-перекази.

По-четверте, існують типові причини неуспішності стартапів, значна частина яких пов'язана з помилками в управлінні інноваційним бізнесом. Узагальнення щодо цих причин, зроблені компанією «СВ Insights», подано на рис. 5.

Як свідчить інформація, подана на рис. 5, основною причиною «провалу» стартапів - 42\% від загальної кількості - виявилося те, що вони не були спрямовані на задоволення реально існуючих потреб. Звідси випливає висновок, що ідея стартапу не може значно «випереджати» потреби споживачів. 


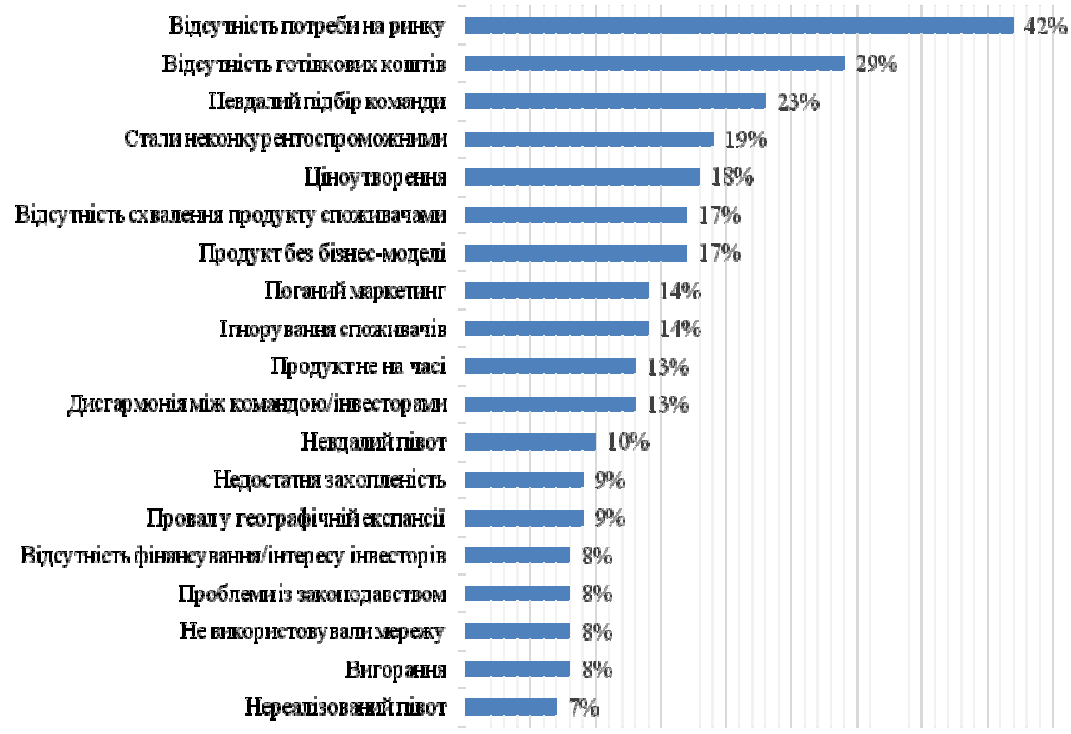

Рис. 5. Визначальні причини невдач стартапів

Джерело: створено авторами самостійно за матеріалами [10].

Сучасна українська економіка не $\epsilon$ економікою інноваційного типу. Країна належить до групи інноваційних аутсайдерів. Однією 3 головних причин такого стану речей, на наш погляд, $є$ інтерес владної верстви суспільства у консервуванні традиційної ресурсно-орієнтованої та не-інноваційної моделі економіки. Попри це, в Україні розвиваються стартапи й сформувався тренд на їх зростання.

Є підстави для таких узагальнень щодо розвитку інноваційного сегменту української економіки та українських стартапів.

Перше. У другій половині 2010-х років відбулося стрімке зростання інвестицій у стартапи. За результатами дослідження Української асоціації венчурного та приватного капіталу (UVCA), динаміка інвестування була такою (рис. 6).

Інформація, подана на рис. 6, свідчить, що в 2017 р. (перший рік помітної стабілізації української економіки) порівняно з 2013 р. (останній рік перед російсько-українською війною) інвестиції в українські стартапи зросли майже в 3 рази. Упродовж одного 2019 р. інвестиції в стартапи збільшилися в 1,5 рази. 


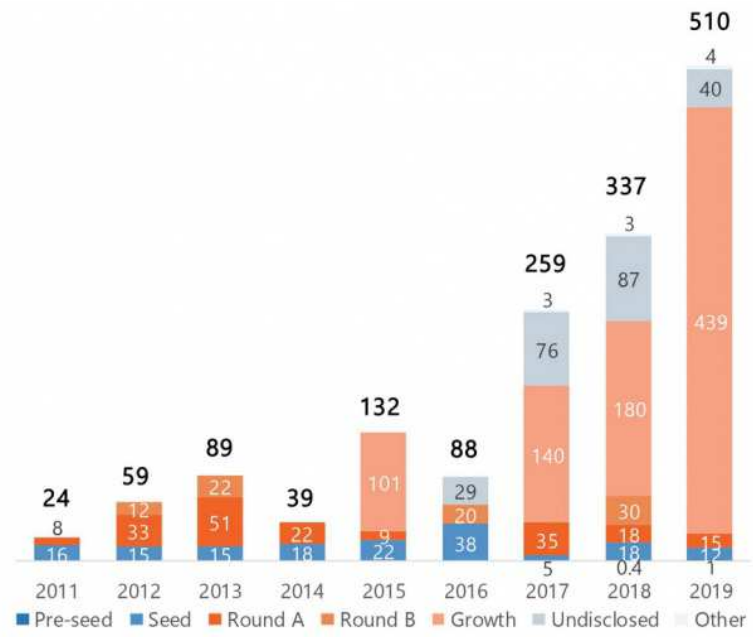

Рис. 6. Інвестиції в українські стартапи за період 2011 - 2019 рр. (млн дол. США)

Джерело: побудовано авторами [11].

Друге. В Україні застосовуються принаймні сім джерел фінансування стартапів, які, за значущістю, ранжуються у такий спосіб $\epsilon[12 ; 13]$ :

- особисті гроші - власні заощадження ініціаторів стартапу;

- гроші друзів та родичів - кошти, отримані в борг у вузькому колі близьких людей з метою організації родинної справи;

- краудфандінг - народне фінансування через спеціалізовані платформи, близьке за змістом до благодійництва заради конструктивної ідеї;

- банківський кредит під розвиток підприємницької ідеї (формально - чинна програма «Доступні кредити 5-7-9\%»);

- бізнес-ангели - поодинокі незалежні інвестори на самих початках розвитку проєкту, іноді за умови участі в управлінні;

- державна участь у фінансуванні (Український фонд стартапів);

- венчурне фінансування - використання коштів вкладників фонду на проєкти з високими ризиками, часто за невигідних для стартапів умов.

На жаль, в Україні такі джерела фінансування стартапів, як державне фінансування, а також за участі венчурних фондів та банків ще не стали визначальними. Саме це відрізняє українську економіку від економік інноваційного типу.

Tpeтє. В Україні загалом створено законодавчу базу для організації інноваційної діяльності та функціонування стартапів. Але їй бракує конкретності, дієвості та політичної волі для реалізації. Основні законодавчі акти подано в табл. 3. 
Таблиия 3

Законодавче поле для діяльності стартапів в Україні

\begin{tabular}{|c|c|c|}
\hline № & Законодавчий акт & Сфера регулювання \\
\hline 1. & $\begin{array}{l}\text { Закон України «Про } \\
\text { інвестиційну діяльність» від } \\
\text { 18.09.1991 р. №1560-XII [14] }\end{array}$ & $\begin{array}{l}\text { Визначає загальні правові, економічні та соціальні } \\
\text { умови інвестиційної діяльності на території України }\end{array}$ \\
\hline 2. & \begin{tabular}{|l|} 
Закон України «Про \\
підприємництво» від 7 лютого \\
1991 р. №698-XII [15]
\end{tabular} & $\begin{array}{l}\text { Визначає загальні правові, економічні й соціальні } \\
\text { засади підприємницької діяльності (підприємництва) } \\
\text { громадян та юридичних осіб на території України, } \\
\text { встановлює гарантії свободи підприємництва та його } \\
\text { державної підтримки }\end{array}$ \\
\hline 3. & \begin{tabular}{|l|} 
Закон України «Про режим \\
іноземного інвестування» від \\
19.03.1996 р. №93/96-ВР [16]
\end{tabular} & $\begin{array}{l}\text { Визначає загальні особливості режиму іноземного } \\
\text { інвестування на території України, виходячи з цілей, } \\
\text { принципів і положень законодавства України }\end{array}$ \\
\hline 4. & $\begin{array}{l}\text { Закон України «Про } \\
\text { інноваційну діяльність» від } \\
\text { 04.07.2002 p. №40-IV [17] }\end{array}$ & $\begin{array}{l}\text { Визначає правові, економічні та організаційні засади } \\
\text { державного регулювання інноваційної діяльності в } \\
\text { Україні, встановлює форми стимулювання державою } \\
\text { інноваційних процесів і спрямований на підтримку } \\
\text { розвитку інноваційної економіки України }\end{array}$ \\
\hline 5. & $\begin{array}{l}\text { Закон України «Про наукові } \\
\text { парки» від 25.06.2009 р. } \\
\text { №1563-VI [18] }\end{array}$ & $\begin{array}{l}\text { Регулює правові, економічні, організаційні відносини, } \\
\text { пов’язані зі створенням і функціонуванням наукових } \\
\text { парків, та спрямований на інтенсифікацію процесів } \\
\text { розроблення, впровадження, виробництва } \\
\text { інноваційних продуктів та інноваційної продукції }\end{array}$ \\
\hline 6. & \begin{tabular}{|l|} 
Закон України «Про авторське \\
право та суміжні права» від \\
23.12.1993 р. №3792-XII [19]
\end{tabular} & $\begin{array}{l}\text { Охороняє особисті (немайнові) й майнові права авторів } \\
\text { та їх правонаступників, пов'язані зі створенням і } \\
\text { використанням творів науки, літератури й мистецтва } \\
\text { (авторське право), і права виконавців, виробників } \\
\text { фонограм та організацій мовлення (суміжні права) }\end{array}$ \\
\hline 7. & $\begin{array}{l}\text { Закон України «Про охорону } \\
\text { прав на винаходи і корисні } \\
\text { моделі» від 15.12.1993 р. } \\
\text { №3687-XII [20] }\end{array}$ & $\begin{array}{l}\text { Регулює відносини, що виникають у зв’язку з набуттям } \\
\text { і здійсненням права інтелектуальної власності на } \\
\text { винаходи та корисні моделі в Україні }\end{array}$ \\
\hline 8. & $\begin{array}{l}\text { Закон України «Про охорону } \\
\text { прав на знаки для товарів і } \\
\text { послуг» від 15.12.1993 р. } \\
\text { №3689-XII [21] }\end{array}$ & $\begin{array}{l}\text { Регулює відносини, що виникають у зв'язку з набуттям } \\
\text { і здійсненням права власності на знаки для товарів та } \\
\text { послуг в Україні }\end{array}$ \\
\hline 9. & $\begin{array}{l}\text { Закон України «Про захист } \\
\text { персональних даних» від } \\
\text { 01.06.2010 p. №2297-VI [22] }\end{array}$ & $\begin{array}{l}\text { Регулює правові відносини, пов'язані із захистом і } \\
\text { обробкою персональних даних, та спрямований на } \\
\text { захист основоположних прав і свобод людини й } \\
\text { громадянина, зокрема права на невтручання в особисте } \\
\text { життя, у зв'язку з обробкою персональних даних }\end{array}$ \\
\hline
\end{tabular}

Джерело: сформовано авторами за матеріалами [23; 24].

3 аналізу українського законодавства випливає, що, створюючи загальні умови підприємницької діяльності та умови інвестування, воно не врегульовує спеціальні умови діяльності стартапів. Останній 3 наведених нормативних документів прийнято 10 років тому. Тому нормативна база не віддзеркалює сучасні умови та особливі потреби підприємців-інноваторів. 
Четверте. В Україні в 2019 р. створено державою спеціальний орган, який покликаний опікуватися діяльністю стартапів - Український фонд стартапів (УФС). Це може бути потрактовано як факт здійснення реальних кроків на шляху підтримки інноваційної діяльності.

Про цілі та пріоритети УФС можна робити висновки з інформації щодо формальних ознак фонду, напрямків фінансування та обсягу коштів, якими він оперує.

Формальні характеристики УФС презентовано в табл. 4.

Таблиия 4

Основні характеристики Українського фонду стартапів

\begin{tabular}{|c|c|}
\hline $\begin{array}{c}\text { Перелік } \\
\text { характеристик }\end{array}$ & Зміст характеристик \\
\hline Форма власності & державна \\
\hline Ініціатор створення & Кабінет Міністрів України \\
\hline Місія фонду & $\begin{array}{l}\text { підтримка інноваційних проєктів та допомога найталановитішим } \\
\text { українським підприємцям у створенні успішних глобальних } \\
\text { компаній }\end{array}$ \\
\hline $\begin{array}{l}\text { Умови } \\
\text { фінансування }\end{array}$ & $\begin{array}{l}\text { - фінансування лише українського бізнесу; } \\
\text { - у формі грантів, а не за рахунок участі в капіталі (від } 25 \text { до } \\
50 \text { тис. дол.); } \\
\text { - фінансування компаніям на початкових стадіях розвитку (рre- } \\
\text { seed та seed); } \\
\text { - фінансування перспективних та інноваційних ідей технологічних } \\
\text { стартапів, які демонструють високий потенціал глобального } \\
\text { комерційного успіху }\end{array}$ \\
\hline Процес відбору & $\begin{array}{l}\text { на конкурсній основі: компанії оцінюються та обираються радою } \\
\text { незалежних інвестиційних експертів }\end{array}$ \\
\hline Цілі фонду & $\begin{array}{l}\text { - підтримка інновацій; } \\
\text { - заохочення підприємництва; } \\
\text { - розвиток економіки; } \\
\text { - збільшення інвестицій; } \\
\text { - створення робочих місць; } \\
\text { - підвищення обізнаності }\end{array}$ \\
\hline Цільові сектори & $\begin{array}{l}\text { - штучний інтелект (AI); } \\
\text { - доповнена реальність (AR/VR) } \\
\text { - великі дані (BigData); } \\
\text { - блокчейн; } \\
\text { - кібербезпека; } \\
\text { - захист (Defence); } \\
\text { - медицина та охорона здоров’я; } \\
\text { - подорожі; } \\
\text { - фінансові технології (FinTech); } \\
\text { - освітні технології (EdTech); } \\
\text { - робототехніка; } \\
\text { - професійні послуги; } \\
\text { - програмне забезпечення як послуга (SaaS); } \\
\text { - виробництво; } \\
\text { - електронна комерція інтернет речей (IoT) }\end{array}$ \\
\hline
\end{tabular}

Джерело: складено авторами за [25]. 
За інформацією 3 табл. 5, Український фонд стартапів має на меті вдосконалення не лише спеціальних умов для розвитку стартапів, а й загальних умов розвитку підприємництва. Незаперечним позитивом його діяльності $є$ прозорий та публічний конкурс проєктів. Фонд фінансує кожний стартап, який виграв конкурс та перебуває на ранніх стадіях розвитку, в сумі 25 тис. дол. Стартап, що функціонує на більш пізніх стадіях, може отримати від фонду 50 тис. дол. Відтак, один стартап, який не припинив діяльності й демонструє зростання, може мати підтримку в сумі 75 тис. дол.

У 2019 - 2020 рр. Фонд фінансував такі українські стартапи на початкових етапах їх становлення (табл. 5).

Таблиия 5

Українські стартапи, які фінансовані у 2019 - 2020 рр. Українським фондом стартапів (у сумі до 25 тис. дол. США)

\begin{tabular}{|c|c|c|c|}
\hline № & $\begin{array}{c}\text { Назва } \\
\text { компанії }\end{array}$ & Зміст стартапу & $\begin{array}{c}\text { Напрям } \\
\text { фінансування } \\
\text { УФС } \\
\end{array}$ \\
\hline 1. & iCorn & $\begin{array}{l}\text { Платформа об’єднує фермерів, покупців } \\
\text { агропродукції, транспортні компанії, елеватори, } \\
\text { лабораторії, банки та страхові компанії, пов’язані з } \\
\text { агробізнесом }\end{array}$ & $\begin{array}{l}\text { Штучний інтелект, } \\
\text { блокчейн, } \\
\text { агротехнології, } \\
\text { Fintech / Legaltech }\end{array}$ \\
\hline 2. & $\begin{array}{l}\text { Caretech } \\
\text { Human }\end{array}$ & $\begin{array}{l}\text { Неперервний автоматичний моніторинг здоров'я та } \\
\text { виявлення хвороб на ранніх стадіях у домашніх умовах }\end{array}$ & $\begin{array}{l}\text { Охорона здоров'я, } \\
\text { штучний інтелект }\end{array}$ \\
\hline 3. & Cittart & $\begin{array}{l}\text { Маркетплейс, розроблений як мобільний додаток, } \\
\text { де будь-який художник або митець зможе легко } \\
\text { розмістити свій артоб'єкт для продажу, а покупець - } \\
\text { оформити замовлення }\end{array}$ & $\begin{array}{c}\text { Big data, } \\
\text { блокчейн, } \\
\text { роздрібна торгівля }\end{array}$ \\
\hline 4. & Sprybuild & $\begin{array}{l}\text { 3D-принтери, полімери та програмне забезпечення } \\
\text { для промислових споживачів, що дозволяє дешево } \\
\text { та швидко виготовляти серійні вироби }\end{array}$ & Промисловість \\
\hline 5. & IOON & $\begin{array}{l}\text { Перший портативний пристрій, що будь-де і будь- } \\
\text { коли перетворює звичайну воду на ефективний у } \\
\text { боротьбі з мікробами санітайзер }\end{array}$ & Охорона здоров’я \\
\hline 6. & Dooozen.io & $\begin{array}{l}\text { Онлайн-сервіс, покликаний звільнити від рутинної } \\
\text { роботи та підвищити продуктивність усіх, хто } \\
\text { активно працює з мережею LinkedIn }\end{array}$ & Медіа та реклама \\
\hline 7. & BioBin & $\begin{array}{l}\text { Мобільний додаток для зменшення впливу на } \\
\text { навколишнє середовище за рахунок кращого } \\
\text { управління споживанням та відходами }\end{array}$ & $\begin{array}{l}\text { Енергетика та } \\
\text { екологія }\end{array}$ \\
\hline 8. & BIOsens & $\begin{array}{l}\text { Перший у світі пристрій, який автоматизує підготовку } \\
\text { зразків, аналіз та збереження результатів у хмарі, } \\
\text { випробування поза лабораторією, але з лабораторною } \\
\text { точністю }\end{array}$ & Агротехнології \\
\hline 9. & Skyworker & $\begin{array}{l}\text { Продукт, який пришвидшує найм IT-спеціалістів у } \\
10 \text { разів з допомогою побудови власної мережі } \\
\text { зв'язків онлайн }\end{array}$ & Big data \\
\hline 10. & Pytag & $\begin{array}{l}\text { Платформа для торгівлі зерном, яка використовує } \\
\text { унікальні алгоритми для збору та обробки всіх } \\
\text { доступних цифрових даних про ринок торгівлі зерном }\end{array}$ & Big data \\
\hline
\end{tabular}

Джерело: [25] інформаиійні дані щзодо профінансованих стартапів УФС станом на 05.07.2020. 
Як свідчить інформація 3 табл. 5, Український фонд стартапів фінансував перші етапи становлення стартапів, діяльність яких була пов'язана з управлінням агробізнесом, 3 охороною здоров'я, з екологією та створенням великих баз даних - Data Base.

На більш пізніх етапах розвитку стартапів Українським фондом стартапів підтримано (в обсязі 50 тис. дол. США) такі підприємтсва (табл. 6)

Таблиия 6

\section{Українські стартапи, які фінансовані у 2019 - 2020 рр.} Українським фондом стартапів (у сумі 50 тис. дол. США)

\begin{tabular}{|c|c|c|c|}
\hline № & $\begin{array}{l}\text { Назва } \\
\text { компанії }\end{array}$ & Зміст стартапу & $\begin{array}{c}\text { Напрям } \\
\text { фінансування } \\
\text { УФС } \\
\end{array}$ \\
\hline 1. & Norm & $\begin{array}{l}\text { Пристрій із вбудованим живленням та технологією } \\
\text { машинного навчання для ефективної і здорової } \\
\text { роботи }\end{array}$ & $\begin{array}{c}\text { Енергетика та } \\
\text { екологія, } \\
\text { штучний інтелект }\end{array}$ \\
\hline 2. & NuWork & CRM-система управління наймом працівників & $\begin{array}{c}\text { Big data, } \\
\text { штучний інтелект }\end{array}$ \\
\hline 3. & FlashBeats & $\begin{array}{l}\text { Мобільний додаток для створення світлових шоу } \\
\text { на музичних та спортивних подіях } \\
\end{array}$ & Спосіб життя \\
\hline 4. & FINMAP & $\begin{array}{l}\text { Онлайн-сервіс для фінансового обліку в малому } \\
\text { та мікробізнесі }\end{array}$ & $\begin{array}{l}\text { Fintech/Legaltech, } \\
\text { освітні технології, } \\
\text { роздрібна торгівля }\end{array}$ \\
\hline 5. & Allzap & \begin{tabular}{|l} 
Платформа для створення інтернет-магазинів 3 \\
продажу автозапчастин та маркет-плейса
\end{tabular} & $\begin{array}{l}\text { Медіа та реклама, } \\
\text { роздрібна торгівля }\end{array}$ \\
\hline 6. & GeoDesign & $\begin{array}{l}\text { Аналітичний онлайн-сервіс, що надає інформацію } \\
\text { про переваги та ризики відкриття магазину/кафе/ } \\
\text { перукарні або інших закладів залежно від локації }\end{array}$ & $\begin{array}{c}\text { Big data, } \\
\text { роздрібна торгівля }\end{array}$ \\
\hline 7. & FRAMIORE & $\begin{array}{l}\text { Формування бренду жіночого одягу з власним } \\
\text { швейним виробництвом та R\&D центром } 3 \\
\text { дослідження, розробки й інновацій текстильних } \\
\text { виробів та технологій }\end{array}$ & $\begin{array}{c}\text { Енергетика та } \\
\text { екологія, } \\
\text { промисловість, } \\
\text { роздрібна торгівля }\end{array}$ \\
\hline 8. & $\mathrm{BIOC}$ & $\begin{array}{l}\text { Технологія нанополімеризації, що дозволяє на } \\
\text { молекулярному рівні зв'язати крохмаль та отримати } \\
\text { біокомпаунд (або біопластик) з високими фізико- } \\
\text { механічними властивостями } \\
\end{array}$ & Промисловість \\
\hline 9. & Cardiolyse & $\begin{array}{l}\text { Платформа для автоматичної інтерпретації } \\
\text { електричних сигналів серця у стані спокою та } \\
\text { Холтер-моніторингу медичного рівня для } \\
\text { визначення } 19 \text { типів аритмій і точного виявлення } \\
\text { більшості аномалій серця } \\
\end{array}$ & Охорона здоров’я \\
\hline 10. & Mate academy & Онлайн-університет IT-професій & Освітні технологіі \\
\hline 11. & ChoiZY & $\begin{array}{l}\text { Профорієнтаційна онлайн-платформа, що допомагає } \\
\text { підліткам обрати професію, а фахівцям - поділитися } \\
\text { досвідом із молоддю }\end{array}$ & Освітні технології \\
\hline 12. & Legal Nodes & $\begin{array}{l}\text { Юридичний маркетплейс, який допомагає } \\
\text { технологічному бізнесу вирішувати юридичні } \\
\text { питання в різних країнах світу } \\
\end{array}$ & Освітні технологіі \\
\hline 13. & SolarGaps & $\begin{array}{l}\text { Система жалюзі із сонячними елементами, які } \\
\text { генерують електроенергію }\end{array}$ & $\begin{array}{c}\text { Енергетика та } \\
\text { екологія }\end{array}$ \\
\hline
\end{tabular}


Продовження табл. 6

\begin{tabular}{|l|l|l|c|}
\hline 14. & $\begin{array}{l}\text { TOВ } \\
\text { СМАРТ- } \\
\text { МАК }\end{array}$ & $\begin{array}{l}\text { Розробка, виробництво та реалізація продуктів і } \\
\text { сервісів для моніторингу споживання будь-яких } \\
\text { ресурсів }\end{array}$ & $\begin{array}{c}\text { Вig data, } \\
\text { енергетика та } \\
\text { екологія }\end{array}$ \\
\hline 15. & $\begin{array}{l}\text { Agrifinance } \\
\text { Online }\end{array}$ & $\begin{array}{l}\text { Формування мережі зв’язків учасників } \\
\text { сільськогосподарського ринку України через } \\
\text { інтегровану та прозору онлайн-екосистему }\end{array}$ & $\begin{array}{l}\text { Fintech / Legaltech, } \\
\text { aгротехнології }\end{array}$ \\
\hline 16. & HarvesTrack & $\begin{array}{l}\text { Нardware та Software (ІоТ) рішення для контролю } \\
\text { процесу збору врожаю та попередження крадіжки } \\
\text { зерна під час жнив }\end{array}$ & Агротехнології \\
\hline 17. & AeroDrone & $\begin{array}{l}\text { Безпілотні літаки з високим корисним } \\
\text { навантаженням та довгою тривалістю польоту }\end{array}$ & Агротехнології \\
\hline 18. & FieldBI & $\begin{array}{l}\text { Комплексна аналітично-експертна система для } \\
\text { покращення рішень для всіх учасників ринку }\end{array}$ & Агротехнології \\
\hline 19. & Unicorn Nest & $\begin{array}{l}\text { Пошук найбільш релевантних інвесторів на } \\
\text { основі власної бази інвесторів та формування } \\
\text { стандарту для фандрейзингу }\end{array}$ & Fintech / Legaltech \\
\hline 20. & Правомен & $\begin{array}{l}\text { Автоматизований помічник з побутових юридичних } \\
\text { питань, включно з формуванням документів та } \\
\text { роз’ясненням можливостей е-сервісів, створених } \\
\text { державою }\end{array}$ & Fintech / Legaltech \\
\hline
\end{tabular}

Джерело: [25] інформаџійні дані щзодо профінансованих стартапів УФС станом на 05.07.2020.

Аналіз стартапів, підтриманих Фондом на етапах їх більш пізнього існування, свідчить про достатньо широке коло пріоритетів. Воно охоплює онлайн-сервіси, агробізнес, екологію, медицину, енергетичну сферу, правове консультування та електронне врядування тощо.

Загалом, з часу заснування у 2019 р. до середини 2020 р. Українським фондом стартапів фінансовано 30 технологічно інноваційних підприємств на загальну суму 1,25 млн дол. США. Причому, за кількістю фінансованих підприємств та обсягом фінансування, перевага надана таким сферам: аграрним технологіям (5 стартапів та 225 тис. дол. США), енергетиці та екології (4 та 175, відповідно), великим базам даних - Big Data (4 та 150, відповідно).

Аналізуючи основні вектори спрямування коштів та потенціал державного фонду підтримки стартапів, маємо підстави для таких узагальнень:

- на жаль, ні в переліку цілей державного фонду, ні в переліку фактично фінансованих стартапів немає тих, які безпосередньо пов'язані 3 військово-промисловим комплексом (ВПК). Останнє $є$ неприродним для країни, що перебуває у стані війни;

- не презентовано напрямок кібербезпеки, актуальність якого зростає в час збільшення економічної невизначеності, зростання кількості кібератак на різні портали та бази даних, включно з державними; 
- загальна сума коштів фонду є достатньо малою й такою, що не може помітно змінити ситуацію в інноваційній сфері.

П'яте. Попри те, що Україна залишається інноваційним аутсайдером і не має необхідної підтримки для розвитку стартапів, інтелектуальний та людський потенціал країни створює передумови для розвитку інноваційного підприємництва. Основні українські стартапи виникають у сфері IT-технологій. За оцінкою «StartupRanking», провідними в Україні в 2019-2020 рр. були 10 стартапів. Вони спеціалізуються на створенні та просуванні вебсайтів, оптимізації й тестуванні для розробників, на програмному забезпеченні онлайнсервісів. Україна з кожним роком посилює свої позиції на міжнародній IT-арені. За висновками українських експертів з UVCA, країна стає $\mathrm{R} \& \mathrm{D}$-хабом для іноземних компаній. В Україні формуються передумови для так званих «інноваційних проривів». Останні створюють образ майбутнього та сприяють його формуванню вже сьогодні. За даними компанії «ADVICE Audit Consulting Group», в Україні створено стартапи, які можуть змінити світ. До таких рушіїв змін належать [26]:

- Carbominer - стартап з вилучення вуглекислого газу з повітря 3 метою його продажу промисловим тепличним комплексам;

- Ecotyre - стартап з переробки спрацьованих автомобільних гумових покришок та металевих домішок, які вони містять;

- Atmosphere - стартап 3 точного прогнозування погоди в межах, що не перевищують 200 метрів від споживача сервісу;

- Minect.ai - стартап з технологією дистанційного розмінування територій Донбасу, замінованих окупантами, за допомогою взаємодії дронів і обладнання для виявлення вибухівки - радарів грунту, металодетекторів, тепловізорів тощо;

- Greenbin.app - стартап, який забезпечує низькі витрати переробки сміття, за рахунок використання привабливої системи стимулів для споживачів продукції;

- Seadora - стартап, спрямований на порятунок Світового океану шляхом мінімізації відходів рибопродуктів та безпосереднє заохочення рибалок.

Існує перелік українських стартапів, здатних закладати сьогодні основи моделі привабливого та сприятливого для людей майбутнього. До таких належать п’ятнадцять стартапів (табл. 7).

Наведений у табл. 7 перелік стартапів стосується екології, добробуту і формування привабливої перспективи, впевненості у майбутньому та економічної й соціальної визначеності. Йдеться не лише про українських громадян, а й про громадян інших країн, оскільки йдеться про вирішення глобальних екологічних проблем. 


\section{П'ятнадцять українських екостартапів світового значення}

\begin{tabular}{|c|l|l|}
\hline № & \multicolumn{1}{|c|}{$\begin{array}{c}\text { Назва } \\
\text { екостартапу }\end{array}$} & \multicolumn{1}{c|}{ Зміст діяльності } \\
\hline 1. & Recycle Map & Інтерактивна мапа пунктів утилізації різних типів відходів \\
\hline 2. & FoodBIOPack & Біорозкладне та їстівне пакування, посуд та столові прибори \\
\hline 3. & Ecoisme & Система економії електроенергії \\
\hline 4. & RE-leaf PAPER & Папір із опалого листя \\
\hline 5. & Effa & Одноразова зубна щітка з переробленого паперу \\
\hline 6. & Re-beau & Прикраси з переробленого пластику \\
\hline 7. & Flushwave & Система повторного використання технічної води \\
\hline 8. & Go Tо-U & $\begin{array}{l}\text { Міжнародна платформа з безкоштовними зарядними станціями для } \\
\text { електромобілів }\end{array}$ \\
\hline 9. & SolarGaps & Жалюзі з сонячними панелями \\
\hline 10. & Stock-factory & $\begin{array}{l}\text { Онлайн-платформа збуту проблемних товарів (пошкоджена упаковка, } \\
\text { наближається термін придатності), що сприяє скороченню обсягів } \\
\text { знищення товарів у торгівельних мережах }\end{array}$ \\
\hline 11. & UGrid & $\begin{array}{l}\text { Сервіс побудови енергетичних мікромереж, що допоможе скоротити } \\
\text { використання викопних джерел енергії та уникнути переплати за } \\
\text { енергопостачання }\end{array}$ \\
\hline 12. & TOKA & Мережа електрозаправок \\
\hline 13. & Nuka & Вічний блокнот та вічний олівець \\
\hline 14. & Water Cloud UA & Пристрій для забору води з повітря \\
\hline 15. & Jollylook & $\begin{array}{l}\text { Екологічно чиста фотокамера з переробленого паперу та картону } \\
\text { для миттєвих знімків }\end{array}$ \\
\hline
\end{tabular}

Джерело: систематизовано авторами за [27-29].

Шосте. Україна активізує співпрацю з міжнародними інститутами, причетними до стимулювання інноваційної діяльності та підтримки стартапів. До прикладу, в 2020 р. Український фонд стартапів узяв участь у формуванні спільної онлайн-платформи 3 підтримки ефективних рішень для подолання світової кризи з фокусом на Східну Європу AC LAB21. Уже підписано Меморандум про співпрацю з міжнародним венчурним фондом Solid5, бізнес-акселератором FeelGoodLabs, Центром підприємництва Українського католицького університету, іншими зацікавленими в розвитку інновацій в Україні учасниками. Міжнародна кооперація відкриває нові можливості для українських стартапів, що не отримали підтримки від українського уряду, мати таку підтримку від міжнародних організацій [25]. Для використання переваг міжнародної співпраці мають бути подолані чинні перепони на шляху отримання та використання українськими підприємцями іноземних коштів для інноваційної діяльності.

Сьоме. В українській економіці й суспільстві сформувалося багато причин, які стримують інноваційну діяльність. На наш погляд, SWOT-аналіз умов для розвитку українських стартапів мав би показати переважання обмежень над факторами сприяння. В усіх дослідженнях 
3 питань інноваційної діяльності виокремлюються ці обмеження. На жаль, поки що відсутні дослідження з обгрунтування ієрархії чинників стримування. Саме таке «негативне рейтингування» факторів впливу могло б створити основу для прийняття обгрунтованих управлінських рішень. 3 урахуванням думки інших дослідників, ми формулюємо припущення про таку ієрархію найважливіших факторів стримування інноваційної діяльності:

- слабкість (обмеженість ресурсів, неструктурованість тощо) українського інвестиційного ринку [30];

- брак державної підтримки інновацій через несформованість інноваційної політики [31] та відсутність політичної волі для ііі здійснення;

- недбале ставлення до ресурсного, насамперед кваліфікованого кадрового потенціалу країни [32];

- незахищеність права власності загалом та права інтелектуальної власності зокрема [33].

3 огляду на існування багатьох факторів стримування інновацій та відсутність послідовної інноваційної політики українських урядів, набувають актуальності дослідження в царині обгрунтування доцільних інструментів стимулювання інноваційної діяльності. На наш погляд, заслуговують на увагу та схвалення рекомендації із застосування таких конкретних інструментів стимулювання [34]:

- «картографування» украӥнської стартап-екосистеми, що передбачатиме створення державного відкритого інтернет-порталу 3 усією необхідною інформацією для підприємців, дослідників, інвесторів та інших зацікавлених в інноваціях осіб;

- приватно-державне партнерство у забезпеченні необхідного рівня освіченості та інтеграції підприємців у міжнародні мережі та спільноти для використання інноваційного досвіду;

- поєднання освіти у сфері IT-технологій та підприємництва для здобуття і використання «цифрових навичок» у практичній діяльності;

- використання стартап-віз - дозволів на проживання для іноземців-ініціаторів стартапів;

- менторські (навчальні, освітні) програми для підприємців 3 метою передачі інноваційного досвіду на постійній основі.

\section{Висновки:}

За результатами дослідження можна зробити такі узагальнення:

- осмислення впливу інноваційного підприємництва та його форми - стартапів - на визначеність національної економіки спирається на усвідомлення взаємозв'язку таких понять (явищ), як: інноваційна діяльність - інноваційне підприємництво - стартапи - інноваційна національна модель розвитку. Віддзеркаленням інноваційної моделі розвитку $\epsilon$ інноваційна політика уряду (держави) 3 властивими їй цілями, пріоритетами та інструментами впливу; 
- характерними інструментами реалізації інноваційної моделі розвитку країнами-інноваційними інсайдерами стають: стабільна частка інноваційних витрат у державному бюджеті, активна діяльність 3 фінансування стартапів венчурними фондами та комерційними банками, постійна участь у міжнародній кооперації в інноваційній сфері та в трансфері технологій. Роль згаданих інструментів сприяння інноваціям не стала вирішальною в українській моделі інноваційної діяльності;

- стартап, як форма інноваційного підприємництва, вирізняється 3-поміж інших форм такими властивостями, як: виникнення у зв'язку з ідеєю принципово нових продукту, послуги, технології, низька ймовірність успішності та значні ризики припинення діяльності, брак інвестиційних ресурсів, спрямованість на швидке зростання та швидке опанування ринку. Саме ці ознаки й стають визначальними при оцінюванні впливу стартапів на економічну невизначеність;

- існують, як мінімум, три напрямки впливу інноваційного підприємництва (стартапів) на економічну невизначеність: а) стартапи перебирають на себе високі ризики інвестування й виконують роль амортизатора для іншого (неінноваційного підприємництва) при масовому тиражуванні інноваційних ідей, б) стартапи виникають та функціонують у сферах, пов'язаних 3 глобальними проблемами у сферах екології, енергетики, охорони здоров'я, стан яких загрожує людству, та забезпечують їх повне або часткове вирішення, в) завдяки стартапам стає зрозумілішим і більш осяжним образ майбутнього, у творенні якого вони беруть безпосередню участь уже сьогодні;

- обмеження інноваційної діяльності, пасивність (бездіяльність) держави в інноваційній сфері або нерезультативна імітація активності органами центральної та місцевої влади означає збільшення масштабів невизначеності національної економіки. За умови політичної волі, український уряд мав би розробити і реалізувати стратегію формування так званої «стартап-екосистеми України» з елементами впливу, вже апробованими в країнах з інноваційною моделлю розвитку.

\section{Лimepamypa:}

1. Горфінкель В. Я. Інноваційне підприємництво. 2015. URL : https://stud.com.ua/21714/ekonomika/innovatsiyne_pidpriyemnitstvo_dosvi d_zarubizhnih_krayin\#49.

2. Blank S. What Founders Need to Know: You Were Funded for a Liquidity Event. Start Looking. 2016. URL : https://steveblank.com/ category/venture-capital.

3. Paul Graham. Before the Startup. 2014. URL : http://www.paulgraham.com/before.html.

4. Рис Э. Бизнес с нуля: Метод Lean Startup для быстрого тестирования идей и выбора бизнес-модели. Москва : Альпина Паблишер, 2012. $253 \mathrm{c}$. 
5. Бланк С., Дорф Б. Священна книга стартапера. Як збудувати успішну компанію / Пер. 3 англ. Н. Валевська. Київ : Наш формат, 2019. $512 \mathrm{c}$.

6. Офіційний вебсайт Про бізнес. Що таке стартап (startup). URL : https://pro-biznes.com.ua/statt-pro-bznes/shho-take-startap-startup.html.

7. Ніщимний В. О. Правові аспекти законодавчого регулювання діяльності стартап-компаній в Україні. URL : https://www.businesslaw. org.ua/pravovi-aspekty-startup/.

8. Жемба А. Й. Світові тенденції впливу інноваційних факторів на економічний розвиток країн в умовах глобалізації. Наукові записки. Серія «Економіка». 2013. Вип. 21. С.16-19.

9. Сайт рейтингу стартапів «StartupRanking». URL : https://www.startupranking.com.

10. The Top 20 Reasons Startups Fail. CB Insights: веб-сайт. URL: https://www.cbinsights.com/research/startup-failure-reasons-top/.

11. Ukrainian Venture Capital and Private Equity Overview 2019. URL : https://www2.deloitte.com/ua/en/pages/press-room/press-release/2020/ investments-into-startups-2019.html\#.

12. Воронцовський В. Стартап - що це таке: визначення та значення терміна, етапи розвитку Startup-проекту + ТОП-10 кращих ідей для стартапу з мінімальними вкладеннями. 22.05.2017. URL : https://itstatti.in.ua/zarobitok-v-interneti/161-startap-shcho-tse-take.html.

13. Що таке стартап простими словами. 29.11.2018. URL : https://uk.binaroption.com/stati/590-chto-takoe-startap-prostymi-slovami.

14. Про інвестиційну діяльність : Закон України від 18.09.1991 р. №1560-XII. URL : https://zakon.rada.gov.ua/laws/show/1560-12\#Text.

15. Про підприємництво : Закон України від 7 лютого 1991 р. №698-XII. URL : https://zakon.rada.gov.ua/laws/show/698-12\#Text.

16. Про режим іноземного інвестування : Закон України від 19.03.1996 p. №93/96-BP. URL : https://zakon.rada.gov.ua/laws/show/93/ 96-\%D0\%B2\%D1\%80\#Text.

17. Про інноваційну діяльність : Закон України від 04.07.2002 p. №40-IV. URL : https://zakon.rada.gov.ua/laws/show/40-15\#Text.

18. Про наукові парки : Закон України від 25.06.2009 р. №1563VI. URL : https://zakon.rada.gov.ua/laws/show/1563-17\#Text.

19. Про авторське право та суміжні права : Закон України від 23.12.1993 p. №3792-XII. URL : https://zakon.rada.gov.ua/laws/show/379212\#Text.

20. Про охорону прав на винаходи і корисні моделі : Закон України від 15.12.1993 р. №3687-XII. URL : https://zakon.rada.gov.ua/ laws/show/3687-12\#Text.

21. Про охорону прав на знаки для товарів і послуг : Закон України від 15.12.1993 р. №3689-XII. URL : https://zakon.rada.gov.ua/ laws/show/3689-12\#Text. 
22. Про захист персональних даних : Закон України від 01.06.2010 p. №2297-VI. URL : https://zakon.rada.gov.ua/laws/show/229717\#Text.

23. Бояринова К. О., Копішинська К. Особливості законодавчого регулювання діяльності стартап-компаній в Україні. Економічний вісник НТУУ «КПI». 2017. №14. С. 393-398.

24. Ніщимний B. О. Правові аспекти законодавчого регулювання діяльності стартап-компаній в Україні. URL : https://www.businesslaw.org.ua/pravovi-aspekty-startup/.

25. Український фонд стартапів. URL : https://usf.com.ua.

26. Лучшие украинские стартапы 2020 TOP Startups, которые изменят Mир URL : https://ua-advice.com/luchshie-ukrainskie-startapy-2020/.

27. 15 українських екостартапів, які підкорюють світ. 23.08.2019. URL : https://www.sfii.gov.ua/15-українських-екостартапів-які-підкор/.

28. Моісеєва М., Голіната А. 15 українських еко-стартапів, які підкорюють світ. 28.02.2019. URL : https://ukrainian.voanews.com/a/ uspishni-ukrainski-ekolohichni-startapy/4794604.html.

29. Проєкт студента КНУ став одним 3 переможців University Startup World Cup 2019. 2019. URL : http://www.univ.kiev.ua/news/ 10695.

30. Вишневецький I. Українські стартапи як надія української економіки URL : https://biz.censor.net.ua/columns/3140403/ukransk_startapi_ yak_nadya_ukransko_ekonomki.

31. Мацкевич Ю. І. Проблеми та перспективи інноваційного розвитку підприємництва в Україні. Теорія та практика управління суб'єктами підприємниитва : колект. моногр. / За заг. ред. Т. В. Гринько. Дніпро : Видавець Біла К. О., 2020. 440 с. С. 195-202.

32. Яковенко В. С. Організаційно-інфраструктурне забезпечення екосистеми стартапів в Україні. Теорія та практика управління суб'єктами підприємництва : колект. моногр. / За заг. ред. Т. В. Гринько. Дніпро : Видавець Біла К. О., 2020. 440 с. С. 379-386.

33. Ніщимний В. О. Правові аспекти законодавчого регулювання діяльності стартап-компаній в Україні. URL : https://www.businesslaw.org. ua/pravovi-aspekty-startup/.

34. Дослідження розвитку екосистем в контексті реалізації стартапів в Україні. Нова хвиля. URL : https://news.ztu.edu.ua/wp-content/ uploads/2019/03/nova-hvylya-1.pdf. 